\title{
Islamic Religious Messages in Local Television Level
}

\author{
Arif Budi Prasetya \\ Political and Social Science Faculty \\ University of Brawijaya \\ Malang, Indonesia \\ arif.budiprasetya@gmail.com
}

\begin{abstract}
The development of the world of media, especially television is not only dominated by the national private media industry alone. However, to be able to touch the social level and religious spirit of society in the region, there is a local private television. For Malang Raya area, the presence of local private television that broadcast syi'ar of Islam is in control of Batu TV. Although based in the Batu City region, but in broadcasting Islam, and other rituals, Batu TV more often broadcast the ritual, to have a special broadcast slot that is Batu TV Syiar. Rituals in the form of ta'lim assemblies, prayer readings, to a great recitation involving religious communities such as Riyadlul Jannah, Jama'ah Ar-Ridwan and others are broadcast through the show. By prioritizing the religion of Islam and the rituals that accompany, Batu TV can be likened to one of the da'wah media for the community, especially in Malang and Batu Tourism City. The concept of a local message that was carried was also not separated by the nuances of Islamic faith and philosophy messages are delivered. This paper intends to provide insight and convey the idea that the message of religious awareness in the perspective of media and religion has been implemented in real practices. In addition, the presence of local private television turned out to give its own color among the community, especially with religious nuances. By seeing that the majority of people in Malang and Batu City are Moslems, the broadcasting of the da'wah's performance can be directly accepted by all society.
\end{abstract}

Keywords—batu tv; syiar; islam message; dakwah media

\section{INTRODUCTION}

The development of communication technology becomes a milestone for mankind, especially in the world of mass communication. In the field of science for example, mass communication has an important role to connect the linkage of people in this world. As we know that communication can be said form of human existence. Communication not only serves as the delivery of messages to the community, but also a form of social reality construction. The function of communication as a social communication at least suggests that communication is essential for building self-concept, self-actualization, for survival, to gain happiness, avoid stress and tension, among others through entertaining communication, and fostering relationships with others. [1].

A conscious human (and cannot) will always communicate. The phrase "We cannot not communicate" is one form of human realization as the most perfect creature. The ability to communicate determines the level of human credibility. Based on the phenomenon, human social life becomes complete. It is conceivable that we, humans, equipped with intelligence and high-level intellectual ability do not communicate at all, instead of engaging in complex social interactions, we will not find the perfect concept of life. The formation of the concept of human life in society certainly begins with the self-concept of each individual. Self-concept is our view of being ready for ourselves, and it can only be obtained through the information that others give us. [1]. Departing from the concept of self that is formed that we begin to move toward the complexity and dynamics in society with an identity that we have.

Communication is formed slowly that is then developed. Starting from intrapersonal communication to mass communication. Starting from the communication between humans to the most modern communication using advanced technology. Everett M Rogers share the development of communication technology into 4 (four) era, namely:

- Writing Era

- Printing Era

- Telecommunication Era

- Interactive Communication Era

Writing Era is an era or period in which humans begin to recognize writing. This era, according to Rogers, is a form of discovery of human self-actualization that finds new ways of communicating by using symbols called letters. The ancient Egyptians used symbols called hieroglyphs as their form of communication through writing. The Chinese also introduced the first article by using certain symbols. The development of writing undergoes a dynamic evolution until we know the letters of the alphabet as it is today.

Printing Era is marked by the invention of the printing press by Gutenberg. The invention of this printing press marked the beginning of the era of communication technology. The first technology that became a stepping stone is this Gutenberg printing machine. Using this machine, Gutenberg spread the controversial pardon of sins. The machine then developed into a newspaper printing press, where the world's first newspaper was Penny Press. Called Penny Press because the time price is only 1 penny, and contains one news only. With the discovery of the printing press by Gutenberg, the rapid development of mass media, especially in the field of print media. More and more print media. The news, which originally contained religious news, the king's message, began to grow with news related to social phenomena. Until now, print media that we 
enjoy every day is the result of the evolution of print media of antiquity. Newspapers are becoming such a primary need for today's modern-day society.

Telecommunication Era is an era where the development of communication technology experienced the golden age. This era is marked by the beginning of the discovery of electronic communication devices remotely. Alexander Graham Bell invented the telegraph and telephone, Guglielmo Marconi found the radio, and Philo T Fansworth found the television. Television discovery is considered as the biggest jump in the world of communications technology, because television became one of the most popular media community because it can deliver audio visual. The event presented also more diverse. In 1928 the General Electronic Company began to organize regular television broadcasts [2].

Interactive Communication Era is the last era according to Rogers, where this is the era of development of the telecommunications era. This era is marked by the discovery of the internet as a new media (new media). The Internet is said to be a new medium because until now it cannot be defined concretely. The Internet is also a form of media convergence, i.e. two forms of media are incorporated into one form of media. This last era also indicates that communication technology is getting more sophisticated. Along with the growing development of communication technology today, humans are required to be able to walk in harmony with these developments. By improving intellectual ability, humans certainly will not be eroded by the times. Technological sophistication followed by the emergence of mass media industries such as newspapers, television, magazines and so forth. Developed countries like the United States, can be said to be a leader in the world of mass media. There are about 1,500 daily newspapers in the United States [3]. With the number of daily newspapers that much, it can be ascertained every second information can be known by the people of the United States.

\section{RESEARCH METHOD}

Mass media becomes an aspect that we can say is inseparable from today's society. The development of media technology has had such a huge impact on society. Various forms of information have been submitted to the public in seconds. This phenomenon has made mass media a means of meeting the needs of the main community. The development of mass media technology in addition to providing forms of social change in society also provides a distinct advantage in society.

When you see the development of the world of communication that is implemented in a television, we know a lot of national and local television. Since its presence in Indonesia in 1962 [4], the study of television is still dominated by research on the ideology of media content and audience acceptance. Similarly, what is happening area of Malang City. The position of local television becomes a new oasis amid the hustle and bustle of national private television. One of the local television in Malang which has the most distinctive event is Batu TV, which broadcast the show syiar. As is known, the population of Malang Raya majority predominantly Islamic, and the position of impressions syi'ar get its own place.

\section{RESULT AND DISCUSSION}

\section{A. Islamic Message in Local Television Impressions}

Islamic religious nuance is a form of viewing that has its own advantages, especially for local television. The moral message delivered in each of his impressions received special attention for the people. The correlation between the context of religious discussion, syi'ar, and the spread of Islamic messages with the concept of religious nuance television has been done by Batu TV. But the main concern in this paper is how the role of local television in conveying messages of Islam in the form of impressions. Notice the following Fig. 1:

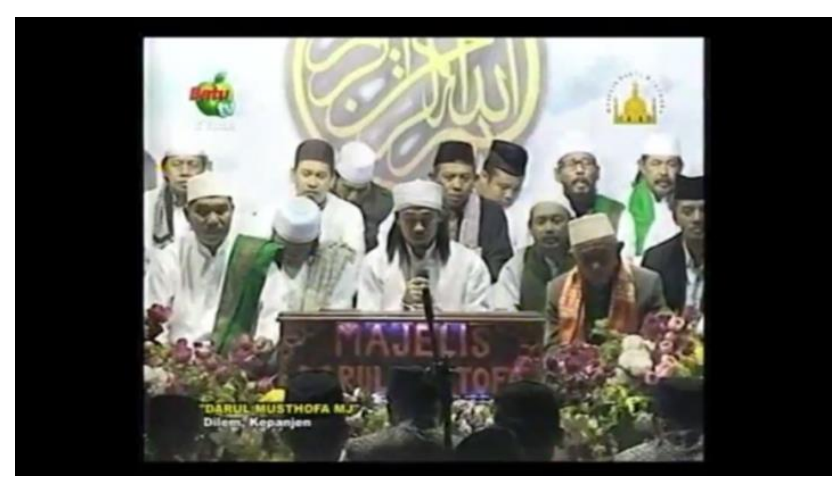

Fig. 1. Darul Mustofa Assembly Review

In the picture we can see how Batu TV performs religious nuances broadcasting. The picture also gives us a statement about the frame made by the local private television station Batu TV. The moral and religious messages contained in each chant of the holy verses of the Qur'an and the Prophet's shalawat provide an overview of the development of local television. The next point, the concept of spreading Islamic messages is not only done by individuals, but, as shown in the picture, there are Islamic organizations that become a forum for the perpetrators of the spread of religious messages.

The message of Islam referred to in this paper is a religious message consisting of several points, namely:

- Message to always remember to Allah SWT.

- The message to always follow the advice of Prophet Muhammad SAW.

- The message to always remember reading the Qur'an

- Messages to always do good to fellow human beings.

- Messages to never leave prayers.

- The message to always remember death, destiny, and doomsday.

The concept of the message of Islam as well as also proves that local television stations facilitate the community to participate in doing syiar. Messages made by the community syiar by establishing relationships with television is not done by individuals. But it is done by Islamic community organizations or Islamic associations. Through the organization, the messages of Islam are delivered and packed by television stations. However, when juxtaposed with the concept of marketing, it is not a discussion in the corridor 
semiotics. Some attributes of Islamic messages are seen in the Fig. 2:

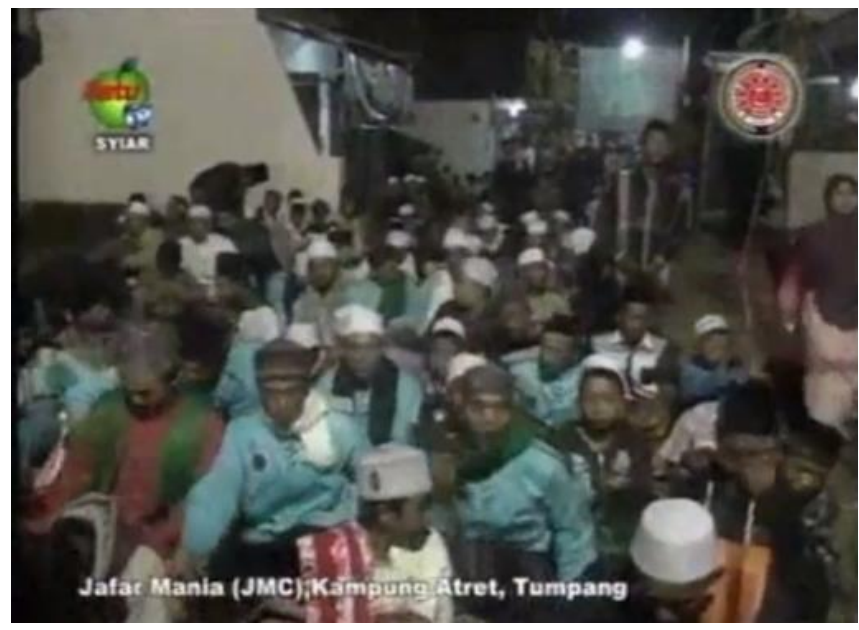

Fig. 2. Community Participant of Assembly

Based on the picture can be seen that the message syi'ar delivered has a considerable impact or effect in the community kalanga. It can be concluded how then the message of syi'ar has its own strength in society. Although in its implementation, it is not uncommon for people to confuse cultural concepts and religious rituals. By Islamic Shari'ah, the concept of recitation of this kind is not contained in the Qur'an or hadith Rasullullah s.a.w. this kind of ritual is a form of gratitude and prayed to God. "Levi-Strauss believes that one of the important limits that every society seeks to understand is the boundary between nature and culture. Culture is the process of understanding that seeks to understand not only the external realm or reality, but also the social system that is part of it, and the social identity and daily activity of those in the system [5]".

\section{B. The Function of Islamic Messages: a Discussion}

Along with the development of the times, the emergence of broadcasts that are based on the concept of religion increasingly vigorous. This is due to the increasing opportunities for the community, community organizations, and government agencies, to fill the impression slot. We take one example, namely Islamic social organizations and associations or religious assemblies of Islam such as Riyadlul Jannah and Ar-Ridwan. As one of the major Islamic organizations, the two assemblies have a massive number of followers (jama'ah). The image and charisma of the organization is able to attract the participants of the assembly in every event they hold. Both in the form of worship and lectures by inviting scholars or kyai are quite respected.

In addition, the culture of the people of East Java, Malang in particular, which is thick with the nuances of Islam, became one of the important factors of the easy spread of Islamic messages through various types of dispersal patterns. Can be through the media or directly. The Islamic messages that are strung together in the form of prayer chanting, the symbolization of the concept of divinity and prophet, and how the interaction between human beings is presented in the form of syi'ar shows through local television. Thus, there is a correlation relevant to the spirit and purpose of society in spreading the message of Islam. Related to the function of these messages of Islam, empirically is a form of reminder (reminder) for man to God.

Another interesting thing is how then the concern of the broadcast world in providing space to "help" the process of the spread. When compared to national television, local television is much more to provide facilities to the concept of this kind of impressions. Private national television, which tends to emphasize the rating and concept of entertainment, certainly much less to give religious nuances like this. Thus, in addition to seeing how the concept of impressions that breathe Islam, it should be noted also about the maintenance of local private television.

\section{CONCLUSION}

After looking at the above description we can see that the concept of religion in the media world when viewed from a semiotic perspective lies in how the media do the construction and framing. The various Islamic messages conveyed by each chaplain or community organization are regarded as religious orders. So the people, massively came to the assembly. Structurally, the concept of dialogue that then occurs between society and society, between preachers with the community and so on, which is called a dialogue horizontally. By emphasizing the concept of religion and humanist, it can be interpreted that the message of Islam that is processed in the assembly of da'wah has been packed well by local television media, with the aim of spreading Islam in a structured and effective.

In its development, I suggest that broadcasting impressions containing such religious concepts need to be continuously developed. In addition, the position of local television as one of the spearhead in reaching the community needs to be maintained and improved. This is because, the national television position is not able to reach the community up to the level of certain areas. One obvious example is how then the mission of an Islamic community organization aimed at spreading the message of Islam can be facilitated through the slot of the syi'ar show as done by the local private television.

\section{REFERENCES}

[1] Mulyana, D. Ilmu Komunikasi Suatu Pengantar. Bandung. Remaja Rosdakarya. 2005.

[2] Ardiyanto, E. Komunikasi Massa Suatu Pengantar Edisi Revisi. Bandung. Simbiosa Rekatama Media. 2007.

[3] Biagi. S. Media/ Impact. Pengantar Media Massa. Penerjemah Muhammad Irfan. Jakarta. Salemba Humanika. 2010.

[4] Bungin, B. Konstruksi Sosial Media Massa. Kencana. Jakarta. 2008.

[5] Fiske, J. Pengantar Ilmu Komunikasi. Penerjemah : Irfan Ibrahim. Yogyakarta. Buku Litera. 2016. 